\title{
Covid-19: FDA approves use of convalescent plasma to treat critically ill patients
}

\author{
Janice Hopkins Tanne
}

New York, USA

The US Food and Drug Administration has approved the use of plasma from recovered patients to treat people who are critically ill with covid-19, provided that doctors get approval over the telephone. ${ }^{1}$

The method has been used in the past to treat diseases such as polio, measles, and mumps, in the 1918 flu epidemic, and in previous outbreaks of respiratory infections similar to covid-19.

The FDA's decision came a day after the New York state governor, Andrew Cuomo, said that the state's health department would begin to treat critically ill patients with convalescent plasma. New York officials said they would recruit patients who have recovered from covid-19, probably from the New York City suburb where the state's outbreak began, NBC News reported. $^{2}$

Cuomo said it was a trial to treat people in a serious condition. He said the state's health department had been working on it, and "We think it shows promise, and we're going to be starting that this week." 2

Plasma from people who have recovered from covid-19 may contain antibodies to the virus that causes the disease and might be effective against the infection, the FDA said. Convalescent plasma has been studied in outbreaks of other respiratory infections, such as H1N1 influenza, SARS, and MERS.

"Although promising, convalescent plasma has not been shown to be effective in every disease studied" and therefore clinical trials were needed to see if it was useful in covid-19, the FDA cautioned.

The FDA told doctors wanting to study the use of convalescent plasma to follow the usual system for an investigational new drug (IND) application.
The plasma must be collected from recovered patients who can donate blood, have had no symptoms for 14 days, and have had negative results on covid-19 tests.

However, given the current public health emergency, the FDA said it was providing emergency access to convalescent plasma for patients "with serious or immediately life threatening covid-19 infections."

Severe disease is defined as dyspnoea, respiratory frequency $\geq 30$ breaths per minute, blood oxygen saturation $\leq 93 \%$, ratio of arterial partial pressure of oxygen to fraction of inspired oxygen $\left(\mathrm{PaO}_{2} / \mathrm{FiO}_{2}\right)<300$, or lung infiltrates $>50 \%$ within 24 to 48 hours.

Life threatening disease is defined as respiratory failure, septic shock, or multiple organ dysfunction or failure.

In such cases, doctors can submit a form online or call FDA's hotline telephone number (1-866-300-4374) to get verbal approval for treatment, which is promised within four to eight hours.

Jeffrey Henderson of Washington University School of Medicine in St Louis, Missouri, told National Public Radio, "The FDA just opened the floodgates. Our institution is scrambling to be ready to use this. There are many others, I'm sure." ${ }^{3}$

1 FDA. Investigational covid-19 convalescent plasma-emergency INDs. https://www.fda gov/vaccines-blood-biologics/investigational-new-drug-ind-or-device-exemption-ideprocess-cber/investigational-covid-19-convalescent-plasma-emergency-inds

2 Hixenbaugh M. FDA will allow doctors to treat critically ill coronavirus patients with blood from survivors. NBC News 2020 Mar 24. www.nbcnews.com/news/us-news/fda-will-allowdoctors-treat-critically-ill-coronavirus-patients-blood-n1167831

3 Palca J. FDA expedites treatment of seriously ill covid-19 patients with experimental plasma. National Public Radio, 24 Mar 2020. www.npr.org/sections/coronavirus-liveupdates/2020/03/24/820939536/fda-expedite-treatment-of-seriously-ill-covid-19-patientswith-experimental-plasma

Published by the BMJ Publishing Group Limited. For permission to use (where not already granted under a licence) please go to http://group.bmj.com/group/rights-licensing/ permissions 